\title{
From Conflict Styles To Behaviours - A Research Of Team Relationship Conflict, And Research Agenda For Indian Infrastructure Projects
}

\author{
Udayan Dasgupta
}

\begin{abstract}
Globally, $80 \%$ of projects fail to meet either schedule or budget, and about $50 \%$ of such failures are due to human factors. Conflict is inevitable between people working in crossfunctional project teams; further, task-oriented conflict is constructive and is needed to make progress. However, personoriented or Relationship Conflict can be destructive - arising from differences in beliefs, values, attitudes and communication styles. Relationship Conflict is found to cause counterproductive work behaviour and affect team cooperation, creativity, cohesion, learning, even mood \& sleep, leading to schedule delays and budget increases, accounting for up to $27 \%$ of the variation in project performance. Several antecedent factors are identified, including team diversity, personality and leadership, with a focus on aspects of behaviour and processes which may be more amenable to control. Among the resolution approaches, the Project Management Institute's style-based proposals are studied, along with later developments which emphasise communication, mediation and negotiation of interests, rather than rights or power. Focussing on behaviour, both destructive and constructive, and the "hot buttons" to control, has been found to provide helpful tools to grow conflict resolution behaviours \& skills, with the necessary organisational commitment. Actual studies of Relationship Conflict behaviour in project teams per se and its impact on performance are limited; particularly in the context of Indian infrastructure projects. A survey is envisaged to assess the current practices and improvement possibilities. The basis and method for conducting such a detailed study are described, with the objective of better management of the phenomenon, enhancing teamwork and improving project performances.
\end{abstract}

Keywords: Relationship Conflict, Conflict Resolution/Management, Project Management

\section{INTRODUCTION}

What distinguishes a project is its transient nature - a temporary grouping of people and resources. It has a definite beginning and end, evolving and changing over time, unlike continuous operations. Central to all projects is the belief that the best outcome can be achieved by grouping specialists from different functions in a "matrix" form. Suitably structured \& empowered teams are formed based on competence, including members who may not have worked together earlier. A contract is agreed with the client defining scopes, time \& cost, which form the iron triangle of execution. (The italicised terms would be different across projects.)

Elgoibar et al. (2017) state that it is natural for people with diverse skills and norms working in teams, making decisions and endeavouring to meet project goals, to have conflicts. Phillips (2011) states that managing conflict is a natural concomitant of teamwork, arising from the "clash of

Revised Manuscript Received on September 10, 2019.

Udayan Dasgupta, Research Scholar, Symbiosis International University, Pune,Maharastra,India. perceptions, goals and values in an arena where people care about the outcome".

Organisations endeavour to use Project Management (PM) "best practices" to promote collaboration by established methods, such as training in HR skills, joint kick-off and review meetings, team-building events, instant messaging and digital communication, frequent statussharing and trouble-shooting, integrated project planning and monitoring.

"Pulse of the Profession" published annually by the Project Management Institute (2017) reveals that globally, $71 \%$ of respondents report embracing "Agile" project management practices, in one form or other. However, $28 \%$ of projects were reported failures, over $30 \%$ of completed projects exceeded the budget, and about $50 \%$ could not be completed on time or had scope creep. Analysis of details in PMI's 2017 survey shows that almost 50\% of project failures can be ascribed to "human factors" during execution: such as behaviour, communication, culture, knowledge, leadership, learning, trust, conflict, competence - following Pasian et al. (2015), as shown below. (Italicised items are factors in relationship conflict). 
Table 1. Primary Causes of Project Failures - top three, from PMI (2017)

\begin{tabular}{|c|c|c|c|}
\hline $\begin{array}{l}\text { Top } 3 \text { Causes of } \\
\text { Project Failure } \\
\text { (as per PMI } \\
\text { survey) }\end{array}$ & $\begin{array}{l}\text { PMI data } \\
\text { (Global } \\
\text { Total) }\end{array}$ & $\begin{array}{l}\text { *Human } \\
\text { Factors } \\
\text { During } \\
\text { Project: }\end{array}$ & $\begin{array}{l}\text { *Other } \\
\text { Factors } \\
\text { in Project }\end{array}$ \\
\hline $\begin{array}{l}\text { Change } \\
\text { organisation's } \\
\text { priorities }\end{array}$ & $41 \%$ & & $9 \%$ \\
\hline $\begin{array}{l}\text { Inaccurate } \\
\text { requirements } \\
\text { gathering }\end{array}$ & $39 \%$ & & $9 \%$ \\
\hline $\begin{array}{l}\text { Change in project } \\
\text { objectives }\end{array}$ & $36 \%$ & & 8 \\
\hline $\begin{array}{l}\text { Inadequate } \\
\text { vision/goal for } \\
\text { project }\end{array}$ & $30 \%$ & $7 \%$ & \\
\hline $\begin{array}{l}\text { Inadequate/poor } \\
\text { communication }\end{array}$ & $30 \%$ & $7 \%$ & \\
\hline $\begin{array}{l}\text { Poor change } \\
\text { management }\end{array}$ & $28 \%$ & $6 \%$ & \\
\hline $\begin{array}{l}\text { Inaccurate cost } \\
\text { estimates }\end{array}$ & $28 \%$ & & $6 \%$ \\
\hline $\begin{array}{l}\text { Undefined } \\
\text { opportunities and } \\
\text { risks }\end{array}$ & $27 \%$ & & $6 \%$ \\
\hline $\begin{array}{l}\text { Inadequate } \\
\text { sponsor support }\end{array}$ & $27 \%$ & $6 \%$ & \\
\hline $\begin{array}{l}\text { Inaccurate } \\
\text { task/time } \\
\text { estimate }\end{array}$ & $26 \%$ & & $6 \%$ \\
\hline $\begin{array}{l}\text { Resource } \\
\text { dependency }\end{array}$ & $23 \%$ & $5 \%$ & \\
\hline $\begin{array}{l}\text { Inadequate } \\
\text { resource } \\
\text { forecasting }\end{array}$ & $23 \%$ & & $5 \%$ \\
\hline $\begin{array}{l}\text { Limited/taxed } \\
\text { resources }\end{array}$ & $22 \%$ & $5 \%$ & \\
\hline $\begin{array}{l}\text { Inexperienced } \\
\text { project manager }\end{array}$ & $20 \%$ & $5 \%$ & \\
\hline Task dependency & $11 \%$ & $3 \%$ & \\
\hline $\begin{array}{l}\text { Team member } \\
\text { procrastination }\end{array}$ & $11 \%$ & $3 \%$ & \\
\hline Other & $11 \%$ & & $3 \%$ \\
\hline Total: & $\begin{array}{l}433 \% \text { (for } \\
3 \text { ) }\end{array}$ & $47 \%$ & $52 \%$ \\
\hline
\end{tabular}

$*$ normalised percentage $=($ Global Total $) \times(100 / 433)$

Pellerin (2009) states that engineers and specialists in complex development projects often have little regard for "touchy-feely-ness", preferring to get on with the job with technical excellence. He believes that the interaction of individuals, how people gel - the "social context" underpins the performance of projects far more than the technical skills, especially when things go wrong. He identifies team "social risk" as a significant impact factor.

Cheung (2015) sees behaviour as having an insidious effect on project delivery. Traditionally, roles are defined in a project but not behaviours - individuals have the flexibility to adopt behaviours. Few people sabotage a project, but unhelpful or undesired behaviour impacts it.

Relationship conflict in project teams can thus be severely debilitating. This aspect of teamwork seems insufficiently addressed, from a behavioural standpoint. PMI's "A Guide to the Project Management Body of Knowledge" or PMBOK Guide, 5th ed. (2013) - the "bible" for new aspirants - has just 1 page in 616 devoted to Conflict Management! Katz \& Flynn (2013) state that most project organisations still lack a detailed understanding of conflict issues and integrated conflict management systems, continuing to use old grievance-type systems.

\section{OBJECTIVE}

The purpose of this paper is to synthesise research underlying our central question "How can we better understand relationship conflict behaviour in project teams?" Having explored the basis, we propose a study of Indian infrastructure projects to facilitate improved resolutions.

\section{DEFINITIONS AND FRAMEWORK}

Team conflict in the literature is of 3 types, namely task, relationship and process conflict:

i) task-oriented or cognitive: from role ambiguity, task interdependence or resource scarcity

ii) person-oriented or relationship, affective or emotional: from attitudes, behaviours, communication style, values or beliefs

iii) process conflict: about task strategy or who should do what

A preliminary search suggested that related studies/journals in psychology, small group research, team performance management, human relations, organisational behaviour, social psychology, cross-cultural management and conflict management could provide insights.

\section{METHODOLOGY}

Both database (Scopus) and manual searches were used. The search query devised was: ((project OR work) AND (team OR group)) AND ((relationship OR emotional OR personal $O R$ affective) AND (conflict $O R$ dispute $O R$ disagreement $O R$ fight)) and variations thereof.

\section{RESULTS OF THE REVIEW}

The studies are collated along the lines of the following themes, as part of the synthesis:

- Impacts of relationship conflict and task conflict

- The interdependence of task and relationship conflict

Antecedents of relationship conflict 
- $\quad$ Role of leadership in relationship conflict

- $\quad$ Processes of informal team conflict resolution

- $\quad$ All-pervading role of trust

- $\quad$ Formal models of team conflict resolution

- Discussion and implications

Each section has a summary table of simplified findings. All discussion is in the last section.

5.1 Impact of Relationship Conflict, compared to Task Conflict

There is no standard definition of project success; it is perceived differently by the organisation management, the project team and other stakeholders, as confirmed by Davis (2014). We find that performance refers to both "outputs" like cost/profit, schedule, safety, operability, quality/reliability, productivity, efficiency/effectiveness, innovation; and to internal "process" parameters like job satisfaction, trust, cohesion, creativity, learning \& employee turnover.

Porter \& Lilly (1996) found that conflict had a stronger negative correlation with performance in complex (decisionmaking or project) tasks than in more straightforward (production) tasks.

\subsubsection{Effects of Task Conflict}

He (2007) found that while task conflict interferes with performance, cognitive capability develops as team members work together and converts task conflict to constructive actions. Hoffart et al. (2015) observed that effective teams engaged in task-related debates, i.e. task conflict, unhindered by interpersonal tensions and logistic disagreements, i.e. low relationship and process conflict. Jehn \& Mannix (2001) found that teams performing well had low but increasing levels of relationship and process conflict and moderate task conflict. Choi \& Sai (2010) found that task conflict increases the group organisational citizenship behaviour (OCB), whereas relationship conflict decreases it. Rispens et al. (2011) found that relationship conflict was associated with counterproductive work behaviour, moderated by group relational closeness. Both relational and task conflict increase avoidance, decrease compromise and confidence; but relational conflict also decreases self-devotion, organisational relations and cooperation/collaboration, contrary to task conflict, as per Qasemi et al. (2014). Meng et al. (2015) saw that relationship conflict between team members negatively affects information-seeking behaviour, but not so task conflict, the former being duly moderated by emotion management. Task conflict was found by Yong et al. (2014) to have a positive relationship with creativity and relationship conflict negative.

\subsubsection{Consequences of Relationship Conflict}

Vaux \& Kirk (2014) found that relationship conflict causes schedule delays and budget increases, mitigated by superior communication and trust. When workload sharing was low, relationship conflict was harmful to performance, as observed by Alipour et al. (2017). Relationship conflict was found by Manata (2016) to hurt both task-based (i.e., decision accuracy) and social-based (i.e., social cohesion) aspects of performance. Zouher Al-Sibaie et al. (2014) found a significant relationship with two factors of conflict: internal and social, which contributed to about $27 \%$ of the variability in project performance. Relationship conflict was involved in the team size-performance relation, via a decrease in team cohesion, as per Espedalen (2016). Quigley et al. (2007) found a 3-way interaction between cohesion, its method of assessment, and relationship conflict on team performance. van Woerkom \& van Engen (2009) found that relationship conflict negatively impacted team learning, which was a significant predictor of performance. Meier et al. (2013) found that relationship conflict influenced angry mood and somatic complaints.

Table 2. Summary of impacts of task \& relationship conflict

\begin{tabular}{|c|c|c|}
\hline Contributory Factors & Impact on Team Process & Impact on Team Output \\
\hline \multicolumn{3}{|l|}{ Task Conflict: } \\
\hline $\begin{array}{l}\text { Time: conflict increases at first, } \\
\text { eventually reduces } \\
\text { Desirable: } \\
\text { moderate task conflict at middle, } \\
\text { low but increasing process conflict, and } \\
\text { low relationship conflict, more at end }\end{array}$ & $\begin{array}{l}\text { - avoidance } \\
\text { - compromise \& confidence } \\
+ \text { task-related debates } \\
+ \text { cognitive capability } \\
+ \text { group OCB } \\
+ \text { self-devotion } \\
+ \text { organisation relations } \\
+ \text { co-operation/collaboration } \\
+ \text { creativity }\end{array}$ & $\begin{array}{l}\text {-interferes with performance } \\
+ \text { beneficial \& constructive } \\
\text { actions } \\
+ \text { effectiveness } \\
+ \text { performance }\end{array}$ \\
\hline Relationship Conflict: & & \\
\hline
\end{tabular}




\begin{tabular}{|l|l|l|}
\hline Low group relational closeness & - group OCB \&counterproductive work & - schedule delays \\
Low emotion management & behaviour & - budget increases \\
Lack of communication \& trust & - avoidance & $-27 \% \quad$ variance \\
Low workload sharing & - compromise \& confidence & performance \\
Large team size & - self-devotion & - decision (in)accuracy \\
& - organisation relations & \\
& - co-operation/collaboration & \\
& -information seeking behaviour & \\
& - creativity & \\
& - social cohesion & \\
\hline
\end{tabular}

(legend: - negative, + positive)

\subsection{Interdependence of Task and Relationship Conflict:}

Simons \& Peterson (2000) found that task and relationship conflict are correlated; however, trust moderates this relationship. Huang (2010) observed that the type of team goal orientation and conflict management approach moderated the relationship. This relationship was weaker under conditions of high team learning but low team performance orientation. The relationship was also weaker among teams that engaged in cooperative conflict management.

\subsubsection{Task Relationship Conflict Transformation}

Choi \& Cho observed that task conflict predicted a subsequent relationship conflict when groups had lower levels of trust. Curseu et al. (2012) found that task conflict has high chance to evolve into relationship conflict when groups have less efficient emotion regulation processes.
Holahan et al. (2011) hypothesised that geographically dispersed teams are likely to trigger affective conflict from task conflict because of higher reliance on technologymediated communication. This has less social and contextual information, higher adverse attribution, more uninhibited behaviour and harsher language than face-toface communication.

\subsubsection{Relationship Task Conflict Correlation}

Parayitam et al. (2010) observed that task conflict in top management teams is related positively to relationship conflict and negatively to agreement-seeking behaviour. Intra-group trust causes agreement-seeking behaviour and collaborating responses. O'Neill et al. (2013) state that team potency and cooperative/competitive/avoidance behaviours affect the linkage.

Table 3. Summary of the interdependence of task $\&$ relationship conflict

\begin{tabular}{|l|l|l|}
\hline Influence & $\begin{array}{l}\text { Causative } \\
\text { factor/context }\end{array}$ & Moderator/curative factor \\
\hline $\begin{array}{l}\text { Task } \square \text { Relationship } \\
\text { (transform, } \\
\text { subsequently) }\end{array}$ & $\begin{array}{l}\text { Lower trust levels } \\
\text { Less efficient emotion } \\
\text { regulation } \\
\text { Geographically } \\
\text { dispersed team }\end{array}$ & $\begin{array}{l}\text { Strengthening mutual trust } \\
\text { Resolving conflicts by co- } \\
\text { operation } \\
\text { Learning-goal oriented team } \\
\text { Individual-team identification }\end{array}$ \\
\hline $\begin{array}{l}\text { Relationship } \rightarrow \text { Task } \\
\text { Conflict }\end{array}$ & $\begin{array}{l}\text { Adverse group affective } \\
\text { behaviour } \\
\text { Competitive } \\
\text { avoidant behaviours and }\end{array}$ & $\begin{array}{l}\text { Agreement-seeking behaviour } \\
\text { Intra-group trust } \\
\text { Cooperative behaviour }\end{array}$ \\
\hline $\begin{array}{l}\text { Task } \square \square \text { Relationship } \\
\text { Conflict }\end{array}$ & $\begin{array}{l}\text { Influence weaker if team } \\
\text { goal orientation is high- } \\
\text { learning \& low- } \\
\text { performance, and there } \\
\text { is cooperative conflict } \\
\text { management }\end{array}$ & $\begin{array}{l}\text { Trust } \\
\text { interpretation processes) }\end{array}$ \\
\hline
\end{tabular}




\subsection{Antecedents of Relationship Conflict}

\subsubsection{Diversity}

Huo et al. (2016) state that intra-personal team diversity, uncertain tasks, cultural diversity, and inappropriate behaviour increase relationship conflict. Rispens et al. (2011) state that relationship conflicts are harmful in relationally distant workgroups in which members are not familiar with and do not feel close to each other. Lount et al. (2011) state that there is a perception of higher relationship conflict when teams are described as "racially diverse" and not "homogeneous". Cognitive diversity, i.e. team-member perceptions also increase relationship conflict and decrease agreement-seeking behaviour as observed by Parayitam et al. (2012). Liang et al. (2007) found that knowledgediversity increases task conflict, which has a positive effect, but values-diversity increased relationship conflict, which reduced performance.

Mohammed \& Agnell (2004) found that the diversity conflict link is moderated by team orientation and process. Team orientation was found to minimise the adverse effects of surface-level (gender) diversity on relationship conflict.

Team processes reduced the damaging effects of "deeplevel" diversity (time urgency) on relationship conflict. Alipour et al. (2017) found that the presence of high powervalues diversity helped to reduce relationship conflict.

\subsubsection{Members' Personality}

Tekleab \& Quigley (2014) found that homogeneity in agreeableness, conscientiousness \& emotional stability and heterogeneity in extraversion \& teamwork preference weakens relationship conflict.

\subsubsection{Team Psychological Safety}

Alipour (2014) found that higher participative safety decreases relationship conflict. Martins et al. (2013) observed that low psychological safety renders expertise diversity to be negative.

\subsubsection{Team Behavioural Integration}

Camelo-Ordaz et al. (2014) observed that behavioural integration mediates effects of team tenure, intra-group trust and value consensus on relationship conflict in top management teams. Vodosek (2000) observed that divergent mental models of appropriate social interaction patterns affect conflict in groups. Marques Santos \& Margarida Passos (2013) found that teams with similar Mental Models (TMM's) have less relationship conflict and better effectiveness.

Table 4. Summary of Antecedent Factors' influence on relationship conflict

\begin{tabular}{|c|c|c|}
\hline Elements of context & $\begin{array}{l}\text { Impact on } \\
R C\end{array}$ & Moderator, if any \\
\hline \multicolumn{3}{|l|}{ Intra-personal team diversity: } \\
\hline $\begin{array}{l}\text {-culture } \\
\text {-relational distance } \\
\text {-racial } \\
\text {-cognitive/perception } \\
\text {-values } \\
\text {-gender } \\
\text {-time urgency } \\
\text {-knowledge } \\
\text {-power value }\end{array}$ & $\begin{array}{l}\text { Negative } \\
\text { ، } \\
\text { ، } \\
\text { ، } \\
\text { " } \\
\text { " } \\
\text { " } \\
\text { Positive } \\
\text { " }\end{array}$ & Team orientation and team process \\
\hline \multicolumn{3}{|l|}{ Members'personality: } \\
\hline $\begin{array}{l}\text {-high extraversion and conscientiousness dyads } \\
\text {-homogeneity in agreeableness, } \\
\text { conscientiousness and emotional stability } \\
\text {-heterogeneity in extraversion and preference } \\
\text { for teamwork }\end{array}$ & $\begin{array}{l}\text { Negative } \\
\text { Positive } \\
\text { Positive }\end{array}$ & \\
\hline \multicolumn{3}{|l|}{ Team Psychological Safety: } \\
\hline $\begin{array}{l}\text {-higher participative safety climate, } \\
\text { psychological safety } \\
\text {-affective commitment } \\
\text {-innovative and teamwork behaviours }\end{array}$ & $\begin{array}{l}\text { Positive } \\
\text { Positive } \\
\text { Positive }\end{array}$ & $\begin{array}{l}\text { Expertise diversity, related to team } \\
\text { performance } \\
\text { Empowering leadership }\end{array}$ \\
\hline \multicolumn{3}{|l|}{ Team Behavioural Integration: } \\
\hline $\begin{array}{l}\text {-constructive-cooperative conflict management } \\
\text { - team tenure, intra-group trust and value } \\
\text { consensus } \\
\text { - similar Team Mental Models (TMM's) }\end{array}$ & $\begin{array}{l}\text { Positive } \\
\text { Positive } \\
\text { Positive }\end{array}$ & \\
\hline
\end{tabular}




\subsection{Role of Leadership in Relationship Conflict}

Ziaaddini et al. (2013) found no direct impact of leadership quality on interpersonal conflict, except the mediating effect of organisational citizenship behaviour. Fodor \& Riordan (1995) found that leaders high in power needs were rated lower in group conflict situations, on cooperative behaviour and analytical task-oriented problem solving, producing lower self-affect among members. Zhou \& Shi (2014) state that leadership may be blamed for higher Relationship Conflict - LMX (leader-member exchange) differentiation was positively related to team relationship conflict, though ethical leadership weakened this relationship. Liu et al. (2015) observed that members' need for affiliation (NAFF) influences relationship conflict, and LMX differentiation has a moderating effect on the relationship of NAFF and relationship conflict. Aw \&
Ayoko (2017) found that transformational leadership incited constructive debate, more than transactional or external leadership styles, but ignited affective conflict among groups. Leaders' transformational behaviours improved the followers' problem-solving conflict behaviours and quality of team member exchange. Kessler et al. (2013) observed that certain proactive leadership behaviours, rather than passive/avoidant models, led to negative emotions and counterproductive work behaviour. Yang \& $\mathrm{Li}$ (2017) found that leaders' conflict-avoidance behaviour was perceived as positive by followers in specific contexts, concerning justice, trust and emotional wellbeing. Kotlyar et al. (2011) observed that pragmatic rather than charismatic leader behaviours ensured higher commitment, restraining dysfunctional conflicts.

Table 5. Summary of Leadership's effect on Relationship Conflict

\begin{tabular}{|c|c|c|}
\hline Leadership aspect & Impact on relationship conflict & Moderator, if any \\
\hline $\begin{array}{l}\text {-leadership quality } \\
\text {-high power needs }\end{array}$ & $\begin{array}{l}\text { None directly } \\
\text { Negative }\end{array}$ & $\begin{array}{l}\text { Organisational citizenship behaviour (OCB) } \\
\text { Leader-member exchange (LMX), ethical } \\
\text { leadership, } \\
\text { Members' need for affiliation (NAFF) }\end{array}$ \\
\hline $\begin{array}{l}\text {-transformational } \\
\text {-proactive }\end{array}$ & $\begin{array}{l}\text { Negative (ignited affective conflict) } \\
\text { Negative (led to counterproductive } \\
\text { behaviour) }\end{array}$ & \\
\hline $\begin{array}{l}\text {-avoidant } \\
\text {-pragmatic, rather than } \\
\text { charismatic }\end{array}$ & $\begin{array}{l}\text { Positive (in the context of justice, trust \& } \\
\text { emotional wellbeing) } \\
\text { Effective (ensures higher commitment, } \\
\text { restrains conflicts) }\end{array}$ & \\
\hline
\end{tabular}

5.5 Processes of Informal Team Conflict Resolution

Five modes of individuals' innate long-term/strategic preferences in handling conflict, also known as styles, were initially proposed by Thomas \& Kilmann (1974) as depicted below. Most of the discussion in the literature on interpersonal conflict is in terms of these "styles".

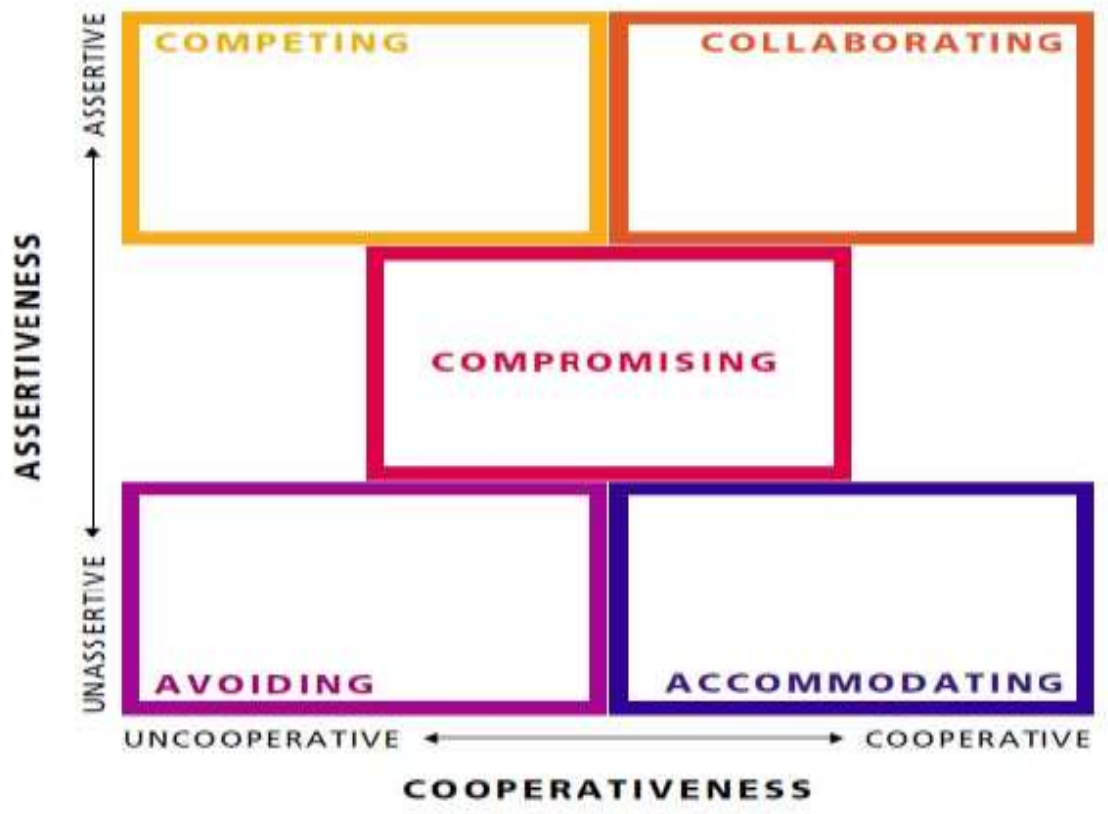

Figure 1: The Five Conflict Management Styles, from Thomas \& Kilmann (1974) 
Prieto-Remon et al. (2015) found that project managers mostly adopt confronting and compromising styles as first options, under the influence (guise?) of responsibility. Jordan \& Troth (2002) observed, however, that individuals with high emotional intelligence consistently preferred to seek collaborative solutions when confronted with conflict.

Ohlendorf (2011) states that project managers may also act as mediators, who aim to assist the parties to find a solution that honours both their interests or at least does not violate their needs. Project managers can help team members find a solution to their dispute and one that is in alignment with the project's scope and needs.

Thiel et al. $(2015,2017)$ found that teams with high initial relationship conflict have worse interpersonal functioning and coordinate less, over the project lifespan. However, teams gradually "rebound" if members tend towards objectively reappraising past affective events and overcame relationship conflict. Changes in perceived threat drive these effects. Sherf \& Shapiro (2013) distinguish between "surfacing" and "discussing" relationship conflict, noting that their effects depend on whether surfacing relationship conflict had yielded relationship repair. The repair was likely to happen if discussions were "accommodating" (refraining from contentious exchanges, despite real or perceived threats). Von Glinow et al. (2004) found that language challenges in multicultural teams can increase the likelihood of emotional conflict and the difficulty of "finding words" in emotional situations. It is questionable whether team members embroiled in emotional conflict should discuss feelings to repair relationships since such members may not share the same meanings. Roschuni et al. (2009) found that high-performing teams with low conflict use high levels of feeling communications. High-conflict teams suppress such communication with feedback. DeChurch et al. (2017) found that conflict processes impact $13 \%$ of the variance in both team performance and satisfaction. Thus, how teams interact regarding their differences are crucial.

Table 6. Summary of conflict style/behaviours \& team processes, positive \& negative

\begin{tabular}{|c|c|c|}
\hline Positive conflict behaviours & Negative conflict behaviours & Context elements if any \\
\hline $\begin{array}{l}\text {-integrating/collaborating } \\
\text { conflict management styles } \\
\text {-avoiding responses } \\
\text {-accommodation and } \\
\text { collaboration } \\
\text { - deep concern for others rather } \\
\text { than no concern } \\
\text { - high emotional intelligence and } \\
\text { pro-social behaviour } \\
\text { - neutral third-party mediation } \\
\text { - objectively reappraising past } \\
\text { affective events } \\
\text { - "surfacing" and "discussing" } \\
\text { relationship conflict } \\
\text {-focusing on the content of } \\
\text { personal interactions rather than } \\
\text { style levels of feeling } \\
\text {-high combunications in messages } \\
\text { commutict } \\
\text {-cooperative conflion and interest-based } \\
\text { management -negotiation and resolution }\end{array}$ & $\begin{array}{l}\text {-compromising style } \\
\text {-collaborating and contending } \\
\text { (competing?) responses } \\
\text {-assertiveness more than } \\
\text { cooperativeness } \\
\text {-an aggressive, confrontational or } \\
\text { domineering tactic } \\
\text {-confronting and compromising } \\
\text { styles }\end{array}$ & $\begin{array}{l}\text { Changes in the perceived threat of early } \\
\text { relationship conflict. Style similar to } \\
\text { "accommodation." } \\
\text { Members embroiled in emotional } \\
\text { conflict } \\
\text { High-performance groups } \\
\text { High performing low-conflict teams } \\
\text { Perceived norms and high volitional } \\
\text { control } \\
\text { Conflict processes impact } 13 \% \text { of the } \\
\text { variance in team performance \& } \\
\text { satisfaction }\end{array}$ \\
\hline
\end{tabular}




\subsection{The All-Pervading Role of Trust}

Conflict in the presence of trust can be beneficial, whereas the absence of trust is almost always deleterious. This gives rise to the question of how teams can increase trust, a psychological state that cannot be either imposed or assumed to exist apriori. Peterson \& Ferguson (2014) suggest that at certain junctures in a project trust and constructive conflict can be encouraged.

\subsection{Formal Models of Team Conflict Resolution}

\subsubsection{The Project Management Institute}

PMI's “A Guide to the Project Management Body of Knowledge" or PMBOK Guide, 5th ed. (2013) states the following on page 283 (reproduced in full because of its importance):

Figure 2: Conflict resolution techniques in PMI's PMBOK Guide, 5th ed.

\subsubsection{Appropriate/Inappropriate Styles}

Building on previous work of similar nature, Spaho [88] proposed a detailed table, elaborating situations in which particular conflict management styles may or may not be suitable.

\subsubsection{Team Mediation System}

Katz \& McNulty (2017) believe that conflict resolution is a communication process for managing conflict and negotiating solutions. This involves defusing any strong emotions and "enabling the disputing parties to understand their differences and similarities". Negotiation is intrinsic to the process, enabling the parties to achieve agreement regarding their interests.

Littlejohn \& Domenici (2000) report that a systemic "team mediation system" is used by companies like Advanced Micro Devices using a communication process of confront - listen - acknowledge - respond - commit, based on five characteristics of constructive conflict management collaboration, power/process/face management and safe environment.

\subsubsection{Alternative Dispute Resolution}

McAleer (2012) proposed an ADR model of project conflict resolution, including techniques of facilitation, negotiation, mediation and an ombudsman, linked to the level of conflict intensity in 5 stages: differences, misunderstandings, disagreements, discord and polarisation.

\subsubsection{Integrated Conflict Management System}

In the USA, where conflict-related costs of employee litigation are high, an ICMS approach has been adopted by companies like Kellogg Brown \& Root as per Lipsky \& Seeber (2004), with the following elements:

ensure conflicts are resolved earliest at the lowest organisational level

emphasise dispute prevention, through interestbased negotiation and problem-solving

a robust ADR program to efficiently resolve disputes that are not prevented

organisational behaviour engendering mutual respect and trust
- training \& rewards ensuring employees have necessary skills

conflict competency as an element of the leadership skill set - "leaders set the tone."

\begin{tabular}{|c|}
\hline 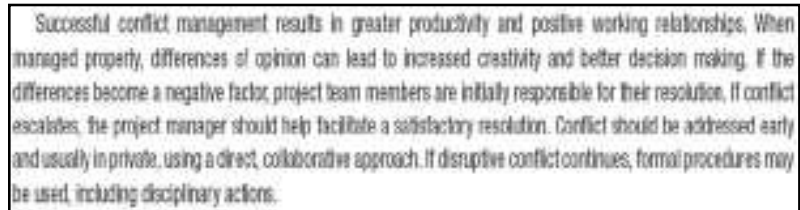 \\
\hline 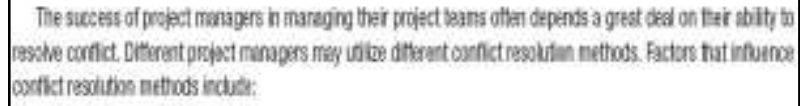 \\
\hline - Felatue importansa and intensty of the onfict. \\
\hline - Time pressun tor rasoling tee cenfict, \\
\hline - fostion baken by sersons involnas, ant \\
\hline 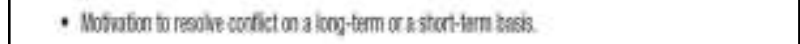 \\
\hline 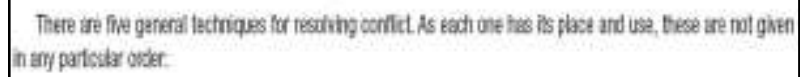 \\
\hline 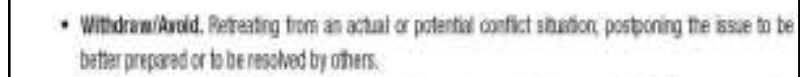 \\
\hline 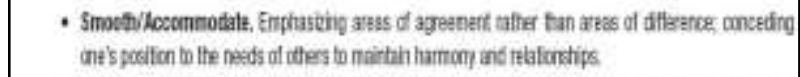 \\
\hline 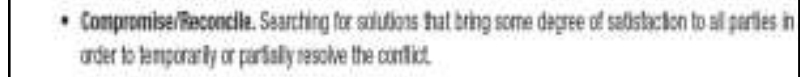 \\
\hline 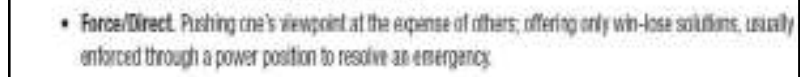 \\
\hline 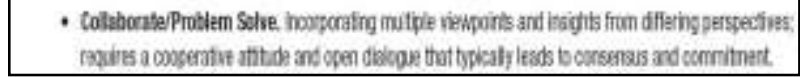 \\
\hline
\end{tabular}

\subsubsection{Conflict Dynamics Profile}

This approach developed by the Center for Conflict Dynamics at Eckerd College in Florida (2001) focuses on conflict behaviours, rather than styles or personality. It tests individuals and teams for constructive \& destructive responses and determines hot buttons to control, helping individuals and teams understand their conflict behaviours and triggers, and how to manage them. The system provides tools to grow necessary behaviours \& skills, not relying on styles.

\subsection{Discussion and Implications}

The devastating negative consequences of relationship conflict on team processes and output are evident from Table 2, underlining its importance for improving project performance. Contributory factors are low team relational closeness, emotion management, communication, trust and workload sharing, besides large team size. In contrast, task conflict is shown to have a beneficial effect on team processes and output.

The interdependence of task and relationship conflict in Table 3 indicates the necessity of isolating them if we are to minimise the negative impacts of relationship conflict while preserving the benefits of task conflict. Favourable conditions for this are identified as mutual trust, cooperation rather than competition or avoidance, team learning not performance orientation, agreement-seeking not emotional behaviour, and closeness or co-location, not dispersion. 
Table 4 indicates that members' given diversity and personality composition predispose teams to relationship conflict, also suggesting that team orientation and team process can help overcome this. The age-old paradigm "behaviour is a function of personality \& environment" is currently restated as "context (i.e. situation) trumps personality" according to Pellerin (2009). Thus, the second set of contextual factors - psychological safety and behavioural integration reduce relationship conflict. One needs to be aware of, and control for, such antecedent factors while studying relationship conflict.

Appropriate leadership is often regarded as a panacea for various organisational ills. However, as indicated in Table 5, the sensitive nature of relationship conflict renders transformational or proactive leadership negative, and avoidant or pragmatic leadership positive - by appearing to do justice, restore trust or wellbeing and ensuring higher commitment. This has an interesting parallel with the Prince 2 and Agile approaches to Project Management which highlight people management and "servant leadership" as key competencies - away from "command and control" to people, behaviour, visioning, autonomy, motivation, influencing \& culture awareness.

Table 6 summarises previous sections on conflict styles/behaviour and processes in order to identify both negative and positive triggers, which exacerbate or ameliorate conflict. Compromising and competing styles are seen to have a negative influence, as do assertive, aggressive, confrontational and domineering tactics, besides difficulties in communication. Conversely, collaborating and accommodating styles reduce conflict, as do behaviours reflecting deep concern for others, pro-social emotional intelligence, processes like reappraising past conflicts, negotiation or third-party mediation.

It appears that the PMBOK recommendations fall short of requirements for lasting conflict resolution. By asking project managers and team members to switch between different styles, which are characteristic of personality type, impractical or unrealistic expectations may be set which are unlikely to result in win-win resolutions. Similar comments apply to Spaho's appropriate/inappropriate bifurcation of styles.

Littlejohn \& Domenici emphasise communication to resolve team conflict and institute a process embracing collaboration and other features, successfully applied by industry.McAleer's proposal of 4-stage ADR linked to the intensity/stage of conflict is exciting, but different from current approaches which recommend that team conflict be "nipped in the bud" as close to inception as possible, it also has no record of application in industry.

ICMS or integrated conflict management system must be regarded as the "Gold Standard" since it incorporates all three elements necessary to make a success of such initiatives:

- $\quad$ Management support and leadership

- $\quad$ Detailed system and process to be followed

- Personnel training and incentives for performance

CDP or conflict dynamics profile is significant in addressing resolution where the conflict begins - behaviour, being more controllable \& changeable than style or personality, with good tools. Successful team conflict resolution, and the models/methods used, rely on learning \& practice by professionals and organisations, as stated by Coleman \& Prywes (2014), just like Agile.

\section{RESEARCH GAPS}

The paucity of studies on conflict behaviour in project teams is striking; the most focus is on antecedent or "structural" factors, which usually cannot be changed during a project. Conflict behaviour in project teams appears to be not readily amenable to control, with rational leadership approaches, and may be worthy of detailed study using appropriate methods.

A granular approach, with focus on controllable behaviours in the team and organisation, may yield conclusions which serve to mitigate a leading problem and improve productivity.

\section{RESEARCH AGENDA}

The study aims to investigate the occurrence and subsidence of relationship conflict and reasons therefor, in a representative sample of infrastructure projects in India. The results may be of benefit to project-based personnel and organisations by developing a more effective "pedagogy" to be learnt/practised, for handling team relationship conflict.

\subsection{Central Question}

How can we better understand relationship conflict behaviour in project teams of infrastructure projects in India? (As a means to facilitating improved resolution/ management). The proposed sub-questions and the research objectives are detailed below: 


\section{Proposed Sub-Questions}

What measures of relationship conflict in project teams are available? Are they reliable and valid? How useful would a measure of "social risk" be?

What are the various manifestations of conflict behaviour in individual/team settings? Which behaviours trigger/increase, and which help to resolve/decrease, relationship conflict?

How frequent and pervasive is relationship conflict in such project teams?

What are the likely impacts of such conflicts on the performance of projects?

What are the predominant conflict management styles/practices adopted?

How effective are they?

Is there a link between conflict type/reason or severity and effective resolution/management practices?

How does the context of infrastructure projects in India affect, and is affected by, behavioural conflict?

What are the training/skilling methods currently used for relationship conflicts? How effective are they?

Have any formal tools of conflict resolution/management been deployed? How effective are they?

\section{SCOPE AND LIMITATIONS}

A class of physical projects is selected, which involves activities of engineering and construction (E\&C) companies building infrastructure, such as transportation, oil \& gas facilities, power plants, in the Indian context. It excludes other types of projects such as software development, $R \& D$ or product development, which operate in different contexts.

\section{PROPOSED METHODOLOGY, TOOLS AND TECHNIQUES}

The research will be mainly qualitative - since we are assessing feelings, opinions, behaviours and practices of project personnel in the target population. An "explanatory synthesis" mixed-method technique is proposed, in two stages:

\section{Quantitative (measurement) Qualitative (assessment) - incidence or prevalence - semi-structured interviews survey (thro' questionnaires) (with seected respondents) - cescriptive/inferential - coding \& thematic analysis statistics (using SPSS) (using NVivo/ATLAStii if needed) \\ Figure 2: 2-stage methodology proposed to be adopted}

The survey will rely on the Critical Incident Technique ask participants to recount an episode of relationship conflict that they experienced/witnessed between team members.

Respondents will be asked to identify behaviours leading to its occurrence and resolution/continuance - including what

\section{Research Objectives}

To review the literature and construct suitable measures, including new ones if needed, of $\mathrm{RC}$ in project teams.

To identify behaviours responsible for the improved/impaired efficiency of project meetings. To examine the communication patterns among team members.

To assess the occurrence and severity of relationship conflicts.

To identify the impacts and estimate the consequences on the performance of projects.

To identify and rank the resolution behaviours currently practised in the industry. To compare different occurrences of relationship conflict, in their need for different resolution approaches.

To construct and validate a relationship between RC types and successful resolution practices.

To classify projects with different type/ client/ contract/ other contexts and differentiate conflict behaviours, if any.

To identify and prioritise the training/skilling needed for relationship conflict resolution in project teams.

To assess the needs for internal/external conflict resolution support/services and their timing.

led to it, what action took place, and what were the consequences. Both Likert-scale items and open-ended questions are proposed, replies to the former will be statistically analysed. Content analysis will be carried out of the survey text answers and interview results, to identify themes. The target population will be Project Managers +/one level in infrastructure-building organisations in India, estimated as 100,000 persons. Purposive sampling will be used to select a representative sample, including the cohorts involved. A survey sample of about 400 qualified respondents is envisaged to maintain the necessary accuracy. Selected 40-50 respondents will be interviewed, to detail/clarify their responses and views.

\begin{tabular}{|l|r|r|}
\hline Conf. Level -> & $95 \%$ & $90 \%$ \\
\hline Error Margin 5\% & 384 & 269 \\
\hline Error Margin 10\% & 96 & 68 \\
\hline
\end{tabular}

Figure 3: Sample size requirements

\section{$X$ ACKNOWLEDGEMENTS}

The author wishes to express sincere gratitude to his Research Supervisor, Dr Rajani Gupte, Professor and ViceChancellor at Symbiosis International University for her encouragement and guidance without which this work would not have been possible. The author also gives thanks to the Central Library officials for support to carry out the Literature Review. Lastly, the author's experience of working with the premier Indian engineering \& construction company Larsen \& Toubro provided valuable insights for this study. 


\section{REFERENCES}

1. Alipour, K. K. (2014). Power Hungry: The Influence of Power Values Diversity on Relationship Conflict and Team Performance. etda.libraries.psu.edu.

2. Alipour, K. K., Mohammed, S., \& Raghuram, S. (2017). Differences in the Valuing of Power Among Team Members: A Contingency Approach Toward Examining the Effects of Power Values Diversity and Relationship Conflict. Journal of Business and Psychology, (2012), 117.

3. Aw, V. K. J., \& Ayoko, O. B. (2017). The impact of followers' conflict behaviors on teams' transformational leadership, team member exchange and engagement. International Journal of Conflict Management, 28(4), 509-532.

4. Camelo-Ordaz, C., García-Cruz, J., \& Sousa-Ginel, E. (2014). Antecedents of relationship conflict in top management teams. International Journal of Conflict Management, 25(2), 124-147.

5. Capobianco, S., Davis, M. H., \& Kraus, L. A. (2001). Conflict dynamics profile technical guide. St. Petersburg: Management Development Institute at Eckerd College.

6. Cheung, A. (2015, June). The impact of behaviour on project delivery. https://www.axelos.com/case-studiesand-white-papers/impact-of-behaviour-on-projectdelivery

7. Choi, J. N., \& Sai, T. (2010). Group-level organizational citizenship behavior: Effects of demographic faultlines and conflict in small work groups. Journal of Organizational Behavior, 31(7), 1032-1054.

8. Coleman, S. W., \& Prywes, Y. (2014). Teaching conflict resolution skills in a workshop. In The handbook of conflict resolution: Theory and practice (3rd ed.). (pp. 849-876).

9. Curşeu, P. L., Boroş, S., \& Oerlemans, L. A. G. (2012). Task and relationship conflict in short-term and longterm groups. International Journal of Conflict Management, 23(1), 97-107.

10. Davis, K. (2014). Different stakeholder groups and their perceptions of project success. International journal of project management, 32(2), 189-201.

11. DeChurch, L. A., Hamilton, K. L., \& Haas, C. (2007). Effects of conflict management strategies on perceptions

12. Elgoibar, P., Euwema, M. \& Munduate, L (2017). Conflict Management. In Oxford Research Encyclopedia of Psychology. New York: Oxford University Press.

13. Espedalen, L. E. (2016). The Effect of Team Size on Management Team Performance: The Mediating Role of Relationship Conflict and Team Cohesion.

14. Fodor, E. M., \& Riordan, J. M. (1995). Leader power motive and group conflict as influences on leader behavior and group member self-affect. Journal of Research in Personality, 29(4), 418-431.

15. He, J. (2007). The moderating effect of cognitive capability on task conflict: A longitudinal study of task conflict and team performance in student software development teams. AMCIS 2007 Proceedings, 23.

16. Hoffart, M. G. Evaluating a Communication Framework for Team Effectiveness in a First-Year Design and Communication Course. age, 26, 1.

17. Holahan, P. J., Mooney, A. C., \& Paul, L. F. (2011). Part I: Managing Conflict and Justice: Moderating Effects of Geographic Dispersion and Team Tenure on the Task-Affective Conflict Relationship. Current Topics in Management, 15, 41-61.

18. Huang, J. (2010). Unbundling task conflict and relationship conflict. International Journal of Conflict Management, 21(3), http://doi.org/10.1108/10444061011063207 of intragroup conflict. Group Dynamics, 11(1), 66-78.

19. Huo, X., Zhang, L., \& Guo, H. (2016). Antecedents of relationship conflict in cross-functional project teams. Project Management Journal.

20. Jehn, K. A., \& Mannix, E. A. (2001). The dynamic nature of conflict: A longitudinal study of intragroup conflict and group performance. Academy of management journal, 44(2), 238-251.

21. Jordan, P. J., \& Troth, A. C. (2002). Emotional Intelligence and Conflict Resolution: Implications for Human Resource Development. Advances in Developing Human Resources, 4(1), 62-79.

22. Katz, N. H., \& Flynn, L. T. (2013). Understanding Conflict Management Systems and Strategies in the Workplace: A Pilot Study. Conflict Resolution Quarterly, 30, 4, 393-410., 30(4), 393-410.

23. Katz, N., \& McNulty, K. (2017). Conflict resolution. City, 2(651), 2121

24. Kessler, S. R., Bruursema, K., Rodopman, B., \& Spector, P. E. (2013). Leadership, interpersonal conflict, and counterproductive work behavior: An examination of the stressor-strain process. Negotiation and Conflict Management Research, 6(3), 180-190.

25. Kotlyar, I., Karakowsky, L., \& Ng, P. (2011). Leader behaviors, conflict and member commitment to teamgenerated decisions. Leadership Quarterly, 22(4), 666679.

26. Liang, T. P., Liu, C. C., Lin, T. M., \& Lin, B. (2007). Effect of team diversity on software project performance. Industrial Management \& Data Systems, 107(5), 636653.

27. Lipsky, D.B. \& Seeber, R.L (2004). "Dispute Resolution in the Changing Workplace", en IRRA Proceedings of the 57 Annual Meeting.

28. Littlejohn, S. W., \& Domenici, K. (2000). Engaging communication in conflict: Systemic practice. Thousand Oaks, CA: Sage

29. Liu, H., Zhou, M., \& Ren, J. (2015). Relations among NAFF, relationship conflict and group performance: The moderating roles of LMX differentiation and task interdependence. 2015 12th International Conference on Service Systems and Service Management, ICSSSM 2015.

30. Lount, R. B., Sheldon, O., Rink, F., \& Phillips, K. (2011). How Much Relationship Conflict Really Exists? Biased Perceptions of Racially Diverse Teams. SSRN Electronic Journal, (October 2016).

31. Manata, B. (2016). Exploring the association between relationship conflict and group performance. Group Dynamics: Theory, Research, and Practice, 20(2), 93104.

32. Marques Santos, C., \& Margarida Passos, A. (2013). Team mental models, relationship conflict and effectiveness over time. Team Performance Management: An International Journal, 19(7/8), 363385.

33. Martins, L. L., Schilpzand, M. C., Kirkman, B. L., Ivanaj, S., \& Ivanaj, V. (2013). A Contingency View of the Effects of Cognitive Diversity on Team Performance: The Moderating Roles of Team Psychological Safety and Relationship Conflict. Small Group Research, 44(2), 96126.

34. McAleer, H. A. (2012). Alternative dispute resolution (ADR) and project management: the need for an ADR model for project success. Paper presented at PMI ${ }^{\circledR}$ Research and Education Conference, Limerick, Munster, Ireland. Newtown Square, PA: Project Management Institute.

35. Meier, L. L., Gross, S., Spector, P. E., \& Semmer, N. K. 
36. (2013). Relationship and task conflict at work: Interactive short-term effects on angry mood and somatic complaints. Journal of Occupational Health Psychology, $18(2), 144-156$

37. Meng, J., Fulk, J., \& Yuan, Y. C. (2015). The Roles and Interplay of Intragroup Conflict and Team Emotion Management on Information Seeking Behaviors in Team Contexts. Communication Research, 42(5), 675-700.

38. Mohammed, S., \& Angell, L. C. (2004). Surface- and deep-level diversity in workgroups: Examining the moderating effects of team orientation and team process on relationship conflict. Journal of Organizational Behavior, 25(8), 1015-1039.

39. O’Neill, T. A., Allen, N. J., \& Hastings, S. E. (2013). Examining the 'Pros' and 'Cons' of Team Conflict: A Team-Level Meta-Analysis of Task, Relationship, and Process Conflict. Human Performance, 26(3), 236-260.

40. Ohlendorf, A. (2011). Conflict Resolution in Project Management Using the Mediation Process.

41. Parayitam, S., Olson, B. J., \& Bao, Y. (2010). Task conflict, relationship conflict and agreement-seeking behavior in Chinese top management teams. International Journal of Conflict Management, 21(1), 94-116.

42. Parayitam, S., Olson, B. J., \& Bao, Y. (2012). Effects of cognitive diversity on relationship conflict, agreementseeking behaviour and decision quality: a study of Chinese management teams. International Journal of Chinese Culture and Management, 3(2), 174

43. Pasian, B., Feldbrugge, K., \& Sankaran, S. (2015). Coverage of 'Human Factors' in project management literature.

44. Pellerin, C. J. (2009). How NASA builds teams: Mission critical soft skills for scientists, engineers, and project teams. John Wiley \& Sons.

45. Peterson, R. S., \& Ferguson, A. J. (2014). Strategies for developing trust through constructive conflict resolution in teams. In Handbook of conflict management research. (pp. 193-204).

46. Phillips, D. (2011). Managing team conflict. [Online]. Center for Human Systems

47. Porter, T. W., \& Lilly, B. S. (1996). The effects of conflict, trust, and task commitment on project team performance. International Journal of Conflict Management, 7(4), 361-376.

48. Prieto-Remón, T. C., Cobo-Benita, J. R., Ortiz-Marcos, I., Uruburu, A., Remón, T. P., Benita, J. R. C., ... Uruburu, A. (2015). Conflict Resolution to Project Performance. Proceedings of the 28th IPMA World Congress, 194(2), 155-164.

49. Project Management Institute (2013), "A Guide to the Project Management Body of Knowledge" (PMBOK® Guide) (5th ed.). PMI Publications, Newtown Square, Pennsylvania

50. Project Management Institute (2017). Pulse of the Profession 2017.

51. Qasemi, H. R., Teymori, J., \& Jahanbakht, E. (2014). Organizational conflict and task groups' behavior. European Online Journal of Natural and Social Sciences, 3(2), 228.

52. Quigley, N. R., Tekleab, A. G., \& Tesluk, P. E. (2007). Aggregation-Based Methods of Measuring Team-Level Variables The Role of Relationship Conflict and Conflict Management Processes. Organizational Research

53. Rispens, S., Greer, L., Jehn, K. A., \& Thatcher, S. M. B. (2011). Not so bad after all: How relational closeness buffers the association between relationship conflict and helpful and deviant group behaviors. Negotiation and Methods, 10(4), 589-608. Conflict Management Research, 4(4), 277-296.

54. Roschuni, C., Oehlberg, L., Beckman, S., \& Agogino, A M. (2009). Relationship Conflict and Feeling Communication in Design Teams. ASME Conference Proceedings, 2009(49057), 955-964.

55. Sherf, E. N., \& Shapiro, D. L. (2013). Should Relationship Conflict in Teams be Surfaced or Ignored? Academy of Management Journal

56. Simons, T. L., \& Peterson, R. S. (2000). Task conflict and relationship conflict in top management teams: The pivotal role of intragroup trust. Journal of Applied Psychology, 85(1), 102-111.

57. Spaho, K. (2013), Organizational communication and conflict management. Management journal, 18(1), 103118 .

58. Tekleab, A. G., \& Quigley, N. R. (2014). Team deeplevel diversity, relationship conflict, and team members' affective reactions: A cross-level investigation. Journal of Business Research, 67(3), 394-402.

59. Thiel, C. E., Harvey, J., Courtright, S., \& Bradley, B. (2017). What Doesn't Kill You Makes You Stronger: How Teams Rebound From Early-Stage Relationship Conflict. Journal of Management, 14920631772902.

60. Thiel, C., Harvey, J., Courtright, S. H., \& Bradley, B. H. (2015). Heating Up and Cooling Down: Relationship Conflict, Emotion Regulation, and Team Processes. Academy of Management Proceedings, 2015(1). http://doi.org/10.5465/AMBPP.2015.322

61. Thomas, K. W., \& Kilmann, R. H. (1974). ThomasKilmann Conflict Mode Instrument. Xicom (Vol. 1).

62. van Woerkom, M., \& van Engen, M. L. (2009). Learning from conflicts? The relations between task and relationship conflicts, team learning and team performance. European Journal of Work and Organizational Psychology, 18(4), 381-404.

63. Vaux, J. S., \& Kirk, W. M. (2014). Relationship conflict in construction management and how it affects performance and profit.

64. Vodosek, M. (2000). Relational models and their effects on relationship, process, and task conflict in work groups. Academy of Management Proceedings, 2000(1), J1-J6

65. Von Glinow, M. A., Shapiro, D. L., \& Brett, J. M. (2004). Can we talk, and should we? Managing emotional conflict in multicultural teams. Academy of Management Review, 29(4), 578-592.

66. Yang, I., \& Li, M. (2017). Can absent leadership be positive in team conflicts? International Journal of Conflict Management, 28(2), 146-165

67. Yong, K., Sauer, S. J., \& Mannix, E. A. (2014). Conflict and creativity in interdisciplinary teams. Small Group Research, 45(3), 266-289.

68. Zhou, M., \& Shi, S. (2014). Blaming leaders for team relationship conflict? The roles of leader-member exchange differentiation and ethical leadership. Nankai Business Review International, 5(2), 134-146.

69. Ziaaddini, M., Taboli, H., \& Nejad, a P. (2013). Investigating the relationship between leadership quality and employees' interpersonal conflict and organizational citizenship behavior. Advances in Environmental Biology, 7(8), 1804-1815.

70. Zouher Al-Sibaie, E., Mohammed Alashwal, A., AbdulRahman, H., \& Kalsum Zolkafli, U. (2014). Determining the relationship between conflict factors and performance of international construction projects. Engineering, Construction and Architectural Management, 21(4), 369 382. 